УДК 637.5

\title{
DEVELOPMENT OF A COMPLEX \\ PROTEIN-MINERAL-CARBOHYDRATE SUPPLEMENT BASED ON ANIMAL PROTEINS
}

\author{
L. Peshuk, O. Gorbach \\ National University of Food Technologies
}

\begin{tabular}{|c|c|}
\hline Key words: & ABSTRACT \\
\hline $\begin{array}{l}\text { Meat products } \\
\text { Chitosan } \\
\text { Protein-mineral- } \\
\text { carbohydrate additive } \\
\text { Animal proteins } \\
\text { Serum protein } \\
\text { concentrate } \\
\text { Amino acid composition }\end{array}$ & $\begin{array}{l}\text { In the article, there were reviewed and conducted a com- } \\
\text { parative analysis of the amino acid composition of dietary } \\
\text { supplements (animal protein, whey protein concentrate) and } \\
\text { developed complex protein-mineral-carbohydrate additive } \\
\text { using animal protein from natural pig meat, milk whey, } \\
\text { chitosan, calcium chloride. The parameters of amino acid } \\
\text { balance were set in order to determine the possibility of } \\
\text { using secondary raw material as an additive to minced meat }\end{array}$ \\
\hline $\begin{array}{l}\quad \text { Article history: } \\
\text { Received } 10.11 .2017 \\
\text { Received in revised form } \\
29.11 .2017 \\
\text { Accepted } 21.12 .2017\end{array}$ & $\begin{array}{l}\text { and target products. Results of the biological value of the } \\
\text { developed protein-mineral-carbohydrate additive confirm } \\
\text { the expediency of its use in the technology of meat products, } \\
\text { as a valuable ingredient for the equivalent replacement of } \\
\text { meat raw material. Received data suggest that the essential }\end{array}$ \\
\hline $\begin{array}{l}\text { Corresponding author: } \\
\text { L. Peshuk } \\
\text { E-mail: } \\
\text { npnuht@ukr.net }\end{array}$ & $\begin{array}{l}\text { amino acids in PMCA are fairly balanced, utilitarian } \\
\text { (rational) factor of amino acid composition of the protein } \\
\text { corresponds to the degree of protein use by organism in } \\
\text { relation to the required physiologically normal. }\end{array}$ \\
\hline
\end{tabular}

DOI: $10.24263 / 2225-2924-2017-23-6-23$

\section{РОЗРОБКА КОМПЛЕКСНОї}

БІЛКОВО-МІНЕРАЛЬНО-ВУГЛЕВОДНОӤ ДОБАВКИ НА ОСНОВІ БІЛКІВ ТВАРИННОГО ПОХОДЖЕННЯ

\author{
Л.В. Пешук, О.Я. Горбач \\ Національний університет харчових технологій
}

У статті вивчено і проведено порівняльний аналіз амінокислотного складу харчових добавок (тваринного білка, концентрату сироваткового білка) $i$ розробленої комплексної білково-мінерально-вуглеводної добавки з використанням тваринного білка з натуральної свинячої сировини, молочної сироватки, хітозану, хлористого кальиію. Встановлено параметри амінокислотної збалансованості з метою визначення можливості використання вторинної сировини як добавки до м'ясних фаршів і циільових продуктів. Результати біологічної иінності розробленої білково-мінерально-вуглеводної добавки підтверджують доиільність ї̈ використання в технології м'ясних виробів як повноцінного інгредієнта для рівноцінної заміни м'ясної сировини. 
Отримані дані дають змогу стверджувати, щяо незамінні амінокислоти в БМВД достатньо збалансовані, коефіцієнт утилітарності (раціональності) амінокислотного складу білка відповідає ступеню використання даного білка організмом стосовно фізіологічно необхідної норми.

Ключові слова: м'ясні продукти, хітозан, білково-мінерально-вуглеводна добавка, тваринні білки, концентрат сироваткового білка, амінокислотний склад.

Постановка проблеми. Підвищення цін на м'ясну сировину призвело до розвитку виробництва інгредієнтів, здатних стати альтернативою м'ясній сировині. Впровадження інноваційних технологій виробництва таких інгредієнтів необхідне для проходження на ринок вітчизняних добавок, виготовлених із вторинної сировини м'ясної та молочної галузей харчової промисловості.

У зв'язку з дефіцитом м'ясної сировини широке застосування отримали білки рослинного і тваринного походження. Ці добавки застосовують при виготовленні всіх видів м'ясних продуктів, в тому числі делікатесних, варено-копчених і сирокопчених виробів. Це сприяє розширенню асортименту запропонованих добавок, покращенню їх функціональних властивостей $\mathrm{i}$ підвищенню рівня безпечності.

Враховуючи вимоги до рівня безпеки продукції, перевагу надають натуральним продуктам, зокрема препаратам тваринних білків, при виготовленні яких головним чином використовують процеси механічної і термічної обробки. Ці білки не містять антихарчових речовин, які знижують харчову цінність готового продукту. Видалення антихарчових речовин 3 рослинної сировини призводить не тільки до подорожчання білкових препаратів, але й до зниження їхніх функціональних властивостей.

Важливу роль у виробництві м'ясної продукції займають тваринні білки, які забезпечують виробничі показники і при грамотному використанні дають змогу вирішити проблеми, пов'язані 3 коливанням якості м'ясної сировини. Білки на основі тваринної сировини мають органолептичні властивості, характерні для м'яса.

Найбільш повноцінними є білки тваринного походження, які 3 успіхом використовуються для здорового та функціонального харчування. 3 рослинних білків - крупи з вмістом 6-16\% білка, 3 яких найбільш цінними $\epsilon$ білки гречаної крупи, вівса, рису, з бобових - сої. В овочах і фруктах міститься 1,2-1,5\% білка. Необхідно, щоб білки були в правильному співвідношенні з іншими харчовими речовинами - вуглеводами, жирами, вітамінами. При нестачі цих складових посилюються процеси розщеплення білків. Найчастіше в м'ясній промисловості використовують соєві білки (ізоляти, концентрати, борошно). Соєві ізоляти мають нейтральний запах і смак, не мають спеціального кольору і при введенні в значній кількості з одночасним вилученням нежирного м'яса можуть знижувати інтенсивність кольору i зменшувати смак та аромат готових виробів. Тваринні білки характеризуються різноманітними функціональними властивостями, які вищі за рослинні. Вони відрізняються нейтральним смаком і запахом, що дає змогу вико- 
ристовувати їх без обмежень для зміни смако-ароматичних властивостей. Не містять генетично модифікованих організмів, що підвищує довіру до них споживачів продукції. Все це забезпечує постійне розширення ринку тваринних білків і збільшення потужностей їх виробництва.

Дуже важливо розрізняти поняття тваринного білка як невід'ємного хімічного сполучення всіх живих організмів, з препаратом тваринного білка технологічного інгредієнта м'ясних продуктів.

Залежно від виду використаної сировини тваринний білок можна класифікувати на:

- білки крові;

- яєчні білки, виділені із цільного яйця, із яєчного жовтка та із яєчного білка;

- молочні білки (сироваткові, казеїнати, виділені із незбираного молока);

- колагенові тваринні білки, виділені із свинячої шкурки, свинячого тримінга, яловичої шкурки, яловичого тримінга. Вони прості у використанні, зберігають свої властивості при тривалому зберіганні, забезпечують збільшення виходу готового виробу і. як наслідок, високу рентабельність виробництва.

Введення білків тваринного походження в рецептури покращують споживчі властивості готового продукту, підвищують технологічну стабільність м'ясних систем та економічні показники реалізованих продуктів.

Функціонально-технологічні властивості різних груп тваринних білків відрізняються один від одного і залежать від ряду факторів: виду і структури білка, технологічних умов ( $\mathrm{pH}$ і температури середовища) тощо.

Молочні білкові препарати використовують у технології м'ясних продуктів у вигляді: сухого молока (незбиране або знежирене), сухої молочної сироватки, сироваткових білкових концентратів (вміст білка від 30 до 80\%), казеїну або казеїнатів, а також суміші різних білкових складових молока.

Сухе молоко стало практично невід'ємною складовою рецептур ковбасних виробів преміум-класу. Призначення сухого молока - надання ніжної молочної нотки готовим виробам.

Казеїнат натрія рекомендують для використання в ковбасному виробництві від 1 до 4\% через високі вологозв'язуючі і емульгуючі властивості. У чистому вигляді його використовуються досить рідко через високу собівартість і специфічний смак.

Сироваткові білкові концентрати з високим вмістом білка (70-80\%) самостійно не проявляють яскраво виражених гелеутворюючих властивостей, але в м'ясних системах разом 3 іншими білковими складовими беруть участь у структуроутворенні, здатні підвищувати стабільність готового виробу. В комбінуванні з карагінанами молочні білки проявляють синергічні властивості, що позитивно впливає на покращення консистенції м'ясних продуктів. Використання білкових концентратів обумовлена тим, що вони поєднують високу волозв'язуючу здатність 3 високою розчинністю і низьким рівнем піноутворення.

Сировиною колагенових білків $є$ шкурка і жилки. Основними амінокислотами в колагеновому білка $\epsilon$ гліцин, пролін і оксипролін. Після термо- 
обробки білок утворює міцні желеподібні гелі, що сприяють покращенню консистенції готової продукції, проте утворений гель не володіє термостабільністю і при повторній тепловій обробці (наприклад, варінні сосисок у воді) може плавитись. У сухій речовині міститься до $99 \%$ чистого волокнистого білка [8].

Переваги використання колагенвмісного білка: підвищення вологозв'язуючих властивостей м'ясних систем, збільшення виходу і покращення структурно-механічних характеристик готових виробів. Регламентовано використання 0,5-2\% таких білків до маси готових виробів, проте вони знижують харчову цінність готових м'ясних виробів, оскільки колаген - не повноцінний тваринний білок, рівень гідратації колагенвмісних білків дуже високий - 1: $10-20$.

Аналіз властивостей і призначення в м'ясній промисловості різних видів тваринних білків (колагенвмісних, молочних, крові, яєць) дає змогу достатньо повно розкрити їх переваги та недоліки. Завдяки своїй харчовій цінності і функціонально-технологічним властивостям тваринний білок $є$ альтернативою соєвим білковим продуктам.

Аналіз літературних джерел показав, що, крім традиційної м'ясної сировини, доцільно використовувати інгредієнти як тваринного, так і рослинного походження, зокрема хітозану, для надання розробленому продукту функціональних властивостей і необхідної направленості [2].

Теоретичні дані по білкам тваринного походження і практичний досвід їх використання в технології м'ясних виробів показує, що доцільно застосовувати їх в поєднанні 3 полісахаридами (камеді, карагінани, модифіковані крохмалі), а також комбінувати з соєвими білками та полісахаридами.

Хітозан - полісахарид, харчове волокно тваринного походження. За своєю природою хітин $є$ одним із трьох найбільш поширених полісахаридів, після целюлози і крохмалю. Він займає друге після целюлози місце як найбільш поширена органічна сполука на землі. Целюлоза і крохмаль $є$ основними вуглеводнями, які використовуються рослинами як джерела живлення i для побудови клітинних стінок. Крім того, вони знайшли широке застосування в харчовій промисловості. Дослідники і підприємці вбачають такий самий потенціал для хітину. 3 хімічної точки зору целюлоза, крохмаль $\mathrm{i}$ хітин $є$ полісахаридами - полімерами або великими молекулами, що складаються з молекул цукру меншого розміру, нанизаними разом, як перлини на нитку.

Значний інтерес до природного полімеру хітозану обумовлений, насамперед, наявністю у нього низки унікальних властивостей, таких як біосумісність, здатність до біодеструкції, нетоксичність, висока сорбційна ємність стосовно іонів металів [1]. Хітозан одержують шляхом лужної обробки хітину - одного з найбільш поширених у природі полісахаридів, що міститься в панцирах ракоподібних, креветок, кальмарів, водоростях, біомасі грибів, личинках мух. На сьогоднішні обсяги виробництва хітозану у світі складають 3500 т на рік. На відміну від інших полісахаридів, хітозан має у своєму складі первинну аміногрупу, що дає можливість створення на його основі широкого 
спектру похідних при прийнятних умовах синтезу, а також придає йому властивостей хелатного полімеру [6].

Застосування хітозана в харчовій промисловості обумовлене його біологічною активністю, добрими емульгуючою, волоутримуючою і жироутримуючою здатністю (ВУЗ та ЖУЗ), а також властивістю покращувати реологічні характеристики харчової маси [3; 4].

Важливою властивістю цього полісахариду є його здатність взаємодіяти 3 білками, утворювати емульсії, гелі, виступати як стабілізатор і антиоксидант $[2 ; 5]$.

На сьогодні більшість традиційних м'ясопродуктів в Україні не відповідають сучасним вимогам за показниками харчової та біологічної цінності, головним чином через використаня в технологіях неякісної сировини та великої кількості різноманітних домішок із високою вологоутримувальною здатністю. Це є однією з причин відхилення харчового статусу населення від формули збалансованого харчування. Крім того, м'ясопродукти мають певну незбалансованість мінерального складу. Вони значно багатші фосфором, ніж кальцієм. У результаті надлишку фосфору в харчуванні утворюються розчинні солі кальцію, які вилучаються 3 кісткової тканини, що є причиною низки захворювань опорно-рухового апарату, нирок, серцево-судинної системи, тощо. Виходячи з цього, доцільним $є$ використання м'ясних виробів як об’єктів збагачення біоорганічними сполуками кальцію. Оскільки найкраще засвоюваною та метаболічно активною формою кальцію $є$ його комплекс із білком, одним зі шляхів вирішення цієї проблеми є розробка добавок оздоровчого призначення на основі білково-мінерального комплексу й асортименту продуктів харчування з його використанням.

Джерелом легкозасвоюваного кальцію $є$ хлористий кальцій (хлорид кальцію - харчова добавка Е509).

Кальцію хлорид поповнює дефіцит кальцію в організмі. Кальцій бере участь у формуванні кісткової тканини, в процесі згортання крові та регулювання проникності судинної стінки, необхідний для підтримки стабільної серцевої діяльності та скорочення скелетних і гладких м'язів, здійснення процесів передачі нервових імпульсів і нормальної діяльності інших органів і систем. Бере безпосередню участь у переході протромбіну в тромбін, що прискорює зсідання крові.

Комплексне використання тваринних білків, харчових волокон і мінеральних сполук дасть змогу компенсувати негативні властивості окремих компонентів, що забезпечить раціональне використання м'ясної сировини, 3 гарантуванням високих органолептичних властивостей і низькою собівартістю готових м'ясних продуктів. Таким чином, з'явиться реальна можливість не тільки отримувати адекватний прибуток від роботи м'ясопереробних підприємств, але й задовольнити потреби споживачів в якісній продукції.

Метою дослідження $\epsilon$ визначення збалансованості по амінокислотному складу розробленої білково-мінерально-вуглеводної добавки.

Матеріали і методи. Експериментальний етап дослідження полягав у вивченні характеристик сировини - вторинних продуктів переробки м'ясної та молочної галузей, вивченні їх органолептичних характеристик, хімічного 
складу, енергетичної та біологічної цінності. Отримані дані використовували в розрахунках коефіцієнтів потенційної біологічної цінності, різниці амінокислотного скору, утилітарності (раціональності) амінокислотного складу білка, коефіцієнта надлишковості та індексу незамінних амінокислот.

Об'єкт дослідження - технологія комплексної білково-мінерально-вуглеводної добавки (БМВД). Предмет дослідження - колагеновий тваринний білок, концентрат сироваткового білка (КСБ), хітозан, хлористий кальцій, білково-мінерально-вуглеводна добавка. У процесі дослідження використовували хімічні, фізико-хімічні, біохімічні методи досліджень.

На основі отриманих показників для більш повної характеристики сировини й отриманої добавки були розраховані: амінокислотний скор, потенційна біологічна цінність (БЦп), коефіцієнт різниці амінокислотного скору (КРАС), коефіцієнт утилітарності (раціональності), коефіцієнт надлишковості $\left(\sigma_{\text {над })}\right.$ амінокислотного складу білка.

Для отримання зразків БМВД використовували тваринний білок 3 натуральної свинячої сировини, молочний білок з сироватки, хітозан і хлористий кальцій [7; 9].

Результати і обговорення. Важливе значення для забезпечення нашої країни повноцінним білком $\epsilon$ ретельна переробка вторинної сировини білковмісних продуктів. Ученими світу вже інтенсивно досліджуються деякі біоактивні речовини, що виділяються з м'ясної сировини, — м'ясні пептиди. Білки м'яса, крім харчової цінності амінокислот, що їх формують, ще мають додаткову біологічну активність, а саме: антигіпертензивну, антиокислюючу, імуномоделюючу, антимікробну, гіпохолестеролімічну, антитромболітичну та здатність зв'язувати мінеральні речовини.

3 метою визначення можливості використання вторинної сировини як добавки до м'ясних фаршів і цільових продуктів нами вивчено і проведено порівняльний аналіз амінокислотного складу (табл. 1) харчових добавок i встановлено параметри амінокислотної збалансованості (табл. 2).

Харчова цінність білків визначається передусім їх амінокислотним складом. При його аналізі особливу увагу приділяють співвідношенню незамінних $\mathrm{i}$ замінних амінокислот. Тваринні та рослинні білки містять незамінні амінокислоти, але різну кількість. Тваринний білок з плазми крові $є$ повноцінним, тому що містить всі незамінні амінокислоти. Білки колагену - неповноцінні. Соєві білки - збалансовані за амінокислотним складом стосовно еталонного білка, але мають у недостатній кількості сірковмісні амінокислоти.

Таблиия 1. Порівняльний аналіз амінокислотного складу білка різних харчових добавок

\begin{tabular}{|c|c|c|c|c|c|c|c|}
\hline \multirow{2}{*}{$\begin{array}{l}\text { Найменування } \\
\text { амінокислот }\end{array}$} & \multicolumn{2}{|c|}{ Вміст у КСБ } & \multicolumn{2}{|c|}{$\begin{array}{c}\text { Вміст у } \\
\text { тваринному білку }\end{array}$} & \multicolumn{2}{|c|}{ Вміст у ВМВД } & \multirow[t]{2}{*}{$\begin{array}{c}\text { Еталон } \\
\text { ФАО/ВООЗ, } \\
\text { мг/г білка } \\
\end{array}$} \\
\hline & $\begin{array}{c}\text { г/100 мг } \\
\text { продукта }\end{array}$ & $\begin{array}{l}\text { мг/1 г } \\
\text { білка }\end{array}$ & $\begin{array}{c}\text { г/100 мг } \\
\text { продукта }\end{array}$ & $\begin{array}{l}\text { мг/1 г } \\
\text { білка }\end{array}$ & $\begin{array}{c}\text { г/100 мг } \\
\text { продукта }\end{array}$ & $\begin{array}{l}\text { мг/1 г } \\
\text { білка }\end{array}$ & \\
\hline 1 & 2 & 3 & 4 & 5 & 6 & 7 & 8 \\
\hline Валін & 3,92 & 59,8 & 2,53 & 28,16 & 3,66 & 36,69 & 50 \\
\hline
\end{tabular}




\begin{tabular}{|c|c|c|c|c|c|c|c|}
\hline \multicolumn{8}{|c|}{ Продовження табл. 1.} \\
\hline 1 & 2 & 3 & 4 & 5 & 6 & 7 & 8 \\
\hline Ізолейцин & 4,074 & 62,2 & 1,59 & 17,70 & 2,32 & 32,00 & 40 \\
\hline Лейцин & 5,87 & 89,7 & 3,46 & 38,52 & 4,63 & 63,86 & 70 \\
\hline Лізин & 5,63 & 86,0 & 3,78 & 42,08 & 4,63 & 63,86 & 55 \\
\hline Метіонін+цистин & 3,805 & 58,1 & 1,3 & 14,55 & 1,85 & 25,45 & 35 \\
\hline Треонін & 4,67 & 71,3 & 2,0 & 22,27 & 3,14 & 43,31 & 40 \\
\hline $\begin{array}{c}\text { Фенілаланін }+ \\
\text { Тирозин }\end{array}$ & 4,55 & 69,5 & 3,43 & 38,19 & 3,45 & 47,59 & 60 \\
\hline $\begin{array}{c}\text { Сума незамінних } \\
\text { амінокислот } \\
\end{array}$ & 32,52 & 496,6 & 18,09 & 201,47 & 23,68 & 312,75 & 350 \\
\hline Аргінін & 1,59 & 24,27 & 7,03 & 78,26 & 7,04 & 97,1 & \\
\hline Гістидин & 1,59 & 24,27 & 1,01 & 11,24 & 1,65 & 22,76 & \\
\hline $\begin{array}{c}\text { Аспарагінова } \\
\text { кислота }\end{array}$ & 7,13 & 108,85 & 5,69 & 63,34 & 6,97 & 96,14 & \\
\hline Серин & 3,71 & 56,64 & 3,25 & 36,18 & 3,56 & 49,10 & \\
\hline $\begin{array}{c}\text { Глютамінова } \\
\text { кислота }\end{array}$ & 10,18 & 155,42 & 9,03 & 100,51 & 9,14 & 126,07 & \\
\hline Пролін & 4,26 & 65,04 & 11,3 & 125,8 & 9,20 & 140,69 & \\
\hline Гліцин & 1,38 & 21,07 & 18,1 & 201,51 & 7,9 & 108,97 & \\
\hline Аланін & 3,67 & 56,07 & 7,5 & 83,5 & 5,93 & 59,45 & \\
\hline $\begin{array}{c}\text { Сума замінних } \\
\text { амінокислот }\end{array}$ & 33,51 & 511,63 & 62,91 & 700,34 & 51,39 & 700,28 & \\
\hline $\begin{array}{c}\text { Сума } \\
\text { амінокислот* }\end{array}$ & 66,03 & 1008,23 & 81,0 & 1013,09 & 75,07 & 1013,03 & \\
\hline $\begin{array}{c}\text { Співвідношення } \\
\text { НАК/ЗАК }\end{array}$ & & & & & & & \\
\hline
\end{tabular}

*Сума наведена для 17 амінокислот, решту не визначали.

Повноцінні тваринні білки значно переважають рослинні за біологічною цінністю, краще збалансовані за амінокислотним складом, це добрі емульгатори, дають змогу переробляти малоцінну жировмісну сировину, покращують консистенцію і пластичність фаршу, підвищують органолептичні властивості готових виробів (соковитість, зовнішній вигляд), збільшують вихід, дозволяють суттєво знизити собівартість продукту.

Результати аналізу амінокислотного складу білків (табл. 1) у харчових добавках дають змогу стверджувати, що в них наявні всі незамінні і замінні амінокислоти. Так, за вмістом незамінних амінокислот найбільш повноцінним є концентрат сироваткового білка, що містить найбільшу кількість треоніну, вміст якого майже на половину переважає еталонний білок ФАО/ВООЗ, (метіоніну+цистину), лізину та ізолейцину, тобто по всіх амінокислотах кращий за еталон.

Вміст білка складає 89,8\%, серед амінокислот переважають замінні, а саме: гліцин, пролін, глютамінова кислота та аланін. Цей білок не є збалансованим за амінокислотним складом. У розробленій нами БМВД (72,7\% білка) серед незамінних амінокислот переважають лізин (сприяє засвоєнню кальцію організмом, транспортуючи його в кістки, стабільній роботі серця), лейцин запобігає розвитку саркопенії при вікових змінах, треонін (підтримує нормальний білковий обмін, бере участь у синтезі колагену й еластину, 
перешкоджає відкладенню жиру в печінці); серед замінних - пролін, гліцин, глютамінова та аспарагінова кислоти й аргінін.

У результаті аналізу порівняння розрахованих значень АСа встановлено, що тваринний білок поступається стандартному білку ФАО/ВООЗ майже на половину, основна лімітована амінокислота - метіонін+цистин, СКОР якої складає 41,57\%. До речі, ця амінокислота є лімітуючою і в БМВД - 44,14\%. Найвищу потенційну біологічну цінність 90,88\% має КСБ.

Розраховане значення КРАС підтверджує, що тваринний білок містить більше надлишкових амінокислот, які не використовуються організмом на метаболічні процеси порівняно з БМВД і КСБ.

Порівняльний аналіз амінокислотного складу білків харчових добавок i «стандартного» білка наведено за показниками амінокислотної збалансованості (табл. 2). 3 табл. 2 видно, що мінімальний амінокислотний скор серед добавок належить метіонін+цистин (41,57\% у добавці колагенового тваринного білка). В розрахунках показників біологічної цінності скор цієї амінокислоти було прийнято за лімітуючий. Величина потенційної біологічної цінності (БЦп) склала: 84,6 - тваринний білок, 90,88 - концентрат сироваткового білка та 93,66 - білково-мінерально-вуглеводна добавка. Розрахований коефіцієнт різниці амінокислотного скору вказує, що 15,38\% незамінних амінокислот у тваринному білку є збитковими і не можуть бути використані на пластичні потреби.

Таблиия 2. Параметри амінокислотної збалансованості білків харчових добавок

\begin{tabular}{|c|c|c|c|c|c|c|c|}
\hline \multirow{2}{*}{$\begin{array}{l}\text { Найменування } \\
\text { амінокислот }\end{array}$} & \multirow[t]{2}{*}{\begin{tabular}{|c|} 
Еталон \\
ФАО/ВООЗ \\
мг/г білка \\
\end{tabular}} & \multicolumn{2}{|c|}{ Тваринний білок } & \multicolumn{2}{|c|}{\begin{tabular}{|c|} 
Білково-мінерально- \\
вуглеводної \\
добавки
\end{tabular}} & \multicolumn{2}{|c|}{$\begin{array}{c}\text { Концентрат } \\
\text { сироваткового } \\
\text { білка }\end{array}$} \\
\hline & & \begin{tabular}{|c|} 
Вміст, \\
мг/г \\
білка \\
\end{tabular} & \begin{tabular}{|c|}
$\mathrm{AC}_{\mathrm{a}}$ скор \\
амінокис- \\
лоти, \%
\end{tabular} & $\begin{array}{l}\text { Вміст, } \\
\text { мг/г } \\
\text { білка }\end{array}$ & \begin{tabular}{|c|}
$\mathrm{AC}_{\mathrm{a}}$ скор \\
амінокис- \\
лоти, \% \\
\end{tabular} & $\begin{array}{l}\text { Вміст, } \\
\text { мг/г } \\
\text { білка }\end{array}$ & $\begin{array}{c}\mathrm{AC}_{\mathrm{a}} \text { скор } \\
\text { амінокис- } \\
\text { лоти, \% }\end{array}$ \\
\hline 1 & 2 & 3 & 4 & 5 & 6 & 7 & 8 \\
\hline Вміст білка, \% & & $\mathbf{8 9 , 8}$ & & 72,7 & & 65,5 & \\
\hline Валін & 50 & 28,16 & 56,34 & 36,69 & 73,38 & 59,8 & 119,6 \\
\hline Лейцин & 70 & 38,52 & 55,03 & 63,86 & 91,23 & 89,7 & 128,14 \\
\hline Лізин & 55 & 42,08 & 76,51 & 63,86 & 116,11 & 86,0 & 156,36 \\
\hline Ізолейцин & 40 & 17,7 & 44,25 & 32,00 & 80,00 & 62,2 & 155,5 \\
\hline Метіонін+цистин & 35 & 14,55 & 41,57 & 25,45 & 72,71 & 58,1 & 166,0 \\
\hline Фенілаланін+тирозин & 60 & 38,19 & 63,65 & 47,59 & 79,32 & 69,5 & 115,83 \\
\hline Треонін & 40 & 22,27 & 55,68 & 43,31 & 108,28 & 71,3 & 178,25 \\
\hline $\begin{array}{c}\text { Потенційна біологічна } \\
\text { цінність (БЦп) білка, } \\
\%\end{array}$ & & \multicolumn{2}{|c|}{84,62} & \multicolumn{2}{|c|}{93,66} & \multicolumn{2}{|r|}{90,88} \\
\hline \begin{tabular}{|c|} 
Коефіцієнт різниці \\
амінокислотного скору \\
(КРАС),\%
\end{tabular} & & \multicolumn{2}{|c|}{15,38} & \multicolumn{2}{|r|}{6,34} & \multicolumn{2}{|r|}{9,12} \\
\hline $\begin{array}{c}\text { Коефіцієнт } \\
\text { утилітарності } \\
\text { (раціональності), } \\
U \text { частка од. }\end{array}$ & & \multicolumn{2}{|r|}{0,72} & \multicolumn{2}{|r|}{0,81} & \multicolumn{2}{|r|}{0,75} \\
\hline
\end{tabular}




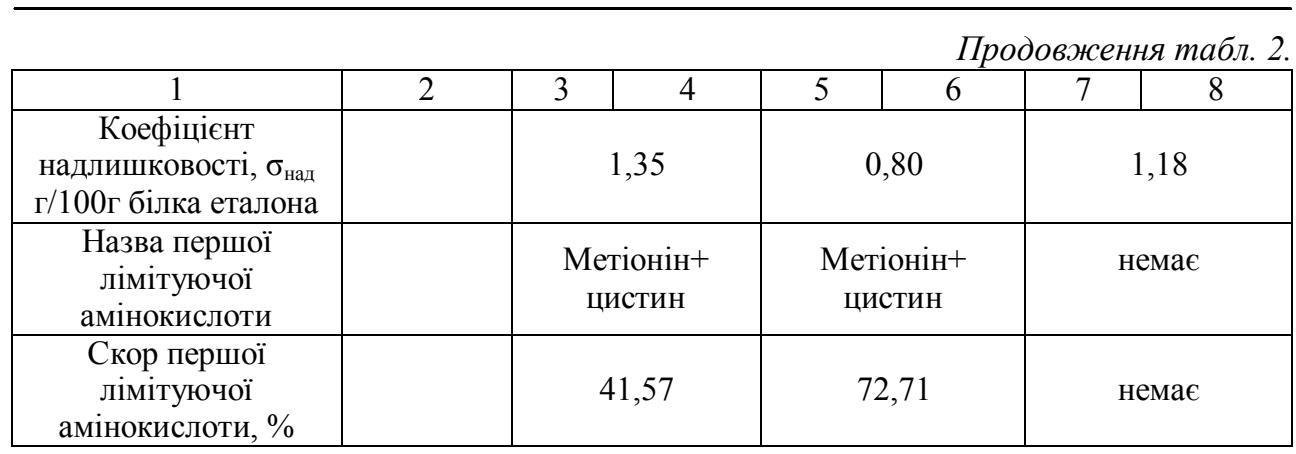

Найкращий результат КРАС отримано в БМВД - 6,34\%. Отримані дані дають змогу стверджувати, що незамінні амінокислоти достатньо збалансовані і на це вказує високий показник коефіцієнта утилітарності (раціональності) амінокислотного складу білка $-0,81$, що відповідає ступеню використання даного білка організмом стосовно фізіологічно необхідної норми. Коефіцієнт надлишковості амінокислотного складу білка характеризує сумарну масу незамінних амінокислот, які не використовуються на анаболічні потреби в такій кількості білка оцінюваного продукту, що еквівалентно за їх потенційно-утилізованим вмістом 100 г білка еталона. Чим менше значення коефіцієнта зіставленої надлишковості, тим краще збалансовані незамінні амінокислоти і тим більш раціонально вони будуть використані організмом. Низьке значення коефіцієнта зіставленої надлишковості у складі білка $-0,8$ г/100 г білка еталона характеризує цю добавку як високоякісне джерело незамінних амінокислот. Ця характеристика якості білка дослідженої добавки також підтверджується низьким коефіцієнтом розбалансованості амінокислотного складу білка. Оцінка біологічної цінності білка дає змогу врахувати вміст всіх незамінних амінокислот у добавці і вказує на те, що БМВД має високу біологічну цінність, індекс незамінних амінокислот якої складає 0,45 . Крім того, у своєму складі містить кальцій і хітозан, що створює передумови до впровадження даної розробки як інгредієнта для рецептур м'ясних виробів цільового призначення.

\section{Висновок}

Таким чином, показники біологічної цінності розробленої білково-мінерально-вуглеводної добавки підтверджують доцільність ії використання в технології м'ясних виробів як повноцінного інгредієнта для загального та спеціального харчування. Отримані дані дають змогу стверджувати, що незамінні амінокислоти в БМВД достатньо збалансовані, коефіцієнт утилітарності (раціональності) амінокислотного складу білка складає 0,81 , що відповідає ступеню використання даного білка організмом стосовно фізіологічно необхідної норми.

У подальшому буде проведено розробку рецептур ковбасних виробів 3 урахуванням попередніх результатів експериментальних досліджень щодо підбору основної сировини, співвідношення складових, рівня заміни м'ясної сировини на БМВД та умови введення добавки при виготовленні фаршевих м'ясних систем. 


\section{Лiтература}

1. Микрочастицы хитозана для получения формы альфа-интерферона пролонгированого действия / А.А. Губайдулина, Г.И. Смагина, А.И. Мелентьев, М.М. Алсынбаев // Биотехнология. - 2010. - № 5.- С.45-50.

2. Антибактериальная и антимикотическая активность хитозана: миханизм действия и роль структуры/ С.Н. Куликов, Ю.А. Тюрин, Р.С. Фассахов // Журнал микробиологии эпидемиологии и иммунобиологии. - 2014. - № $5-$ С. $91-97$.

3. Jull A. B. et al. Chitosan for overweight or obesity / Cochrane Database of Systematic Reviews. - 2008. - Issue 3. - P. 6-32.

4. Sogias I.A., Williams A.C., Khutoryanskiy V.V. Why is chitosan mucoadhesive? Biomacromolecules, 9, 1837-1842 (2008).

5. Casettari L., Illum L. Chitosan in nasal delivery systems for therapeutic drugs // Journal of Controlled Release. - 2014. — \# 190. - P. 189-200.

6. Варламов В.П. Хитин и хитозан: природа, получение и применение/ В.П. Варламов, С.В. Немцев, В.Е. Тихонов. - Щелково : Изд-во Российского Хитинового Общества, 2010. - $292 \mathrm{c}$.

7. Sayas-Barbera E., Quesada J., Sanchaz-Zapata E. Effect of the molecular weight and concentration of chitosan in pork model burgers. //Meat Science 88 (2011). — P. 740 - 749.

8. Peshuk L., Budnyk N., Galenko O.O. Rational use of the collagen / Ukrainian Journal of Food Science.-2014. - Volume 2, Issue 1.- P. 361-370.

9. Пешук Л.В. Застосування хітозану в технології м'ясних продуктів / Л.В. Пешук, О.Я. Горбач, I.C. Лисенко // Технічні науки: наукові здобутки молоді - вирішенню проблем харчування людства у XXI столітті: матер. 82 міжнар. наук. конф. молодих учених, аспірантів і студентів 13-14 квітня 2016 р. — Київ : НУХТ, 2016. — С. 294. 